\title{
«Полеты, не обеспеченные в поисково-спасательном отношении, запрещаются...»: к вопросу о боевом применении авиации 40-й армии в Афганистане в 1979-1989 гг.
}

\author{
В.В. Гагин \\ Военно-воздушная академия имени профессора Н.Е. Жуковского и Ю.А. Гагарина (г. Воронеж), \\ Россия, 394064, г. Воронеж, ул. Старых Большевиков, 54а \\ E-mail: generals78@mail.ru
}

\begin{abstract}
Аннотация. Статья посвящена анализу боевого опыта ВВС СССР в период участия советских войск в войне в Афганистане в 1979-1989 гг. Специфика горно-пустынной местности и климатические условия этой страны свойственны практически всем государствам, с которыми граничит Российская Федерация на юге, начиная от Закавказья и Средней Азии и заканчивая Китаем и Монголией на Дальнем Востоке. Боевой опыт, приобретенный тогда Военно-воздушными силами, сегодня важен не только из-за очень высокой цены, заплаченной в 1979-1989 гг. в Афганистане кровью и жизнями солдат и офицеров, но и своей актуальностью. Техника и вооружение, которые сейчас используются российскими ВКС, во многих своих компонентах остались либо те же, либо в разной степени модернизированные, следовательно, формы и методы работы с ними - эксплуатация, техническое обслуживание, снабжение и т. д. - прежние. Кроме технических вопросов ветераны войны в Афганистане - военачальники и командиры самых разных рангов и уровней - всячески подчеркивают, что особую роль играют вопросы взаимодействия и управления. Во избежание отрицательных факторов в организации и проведении боевых действий из-за слабо поставленного взаимодействия сухопутных войск и авиации необходимо постоянное совершенствование управления. Подготовленные крупные операции, как правило, проходят без больших потерь, тогда как мелкие неподготовленные часто ведут к поражению. Поэтому опыт организации взаимодействия больших операций необходимо всегда переносить и на малые.
\end{abstract}

Ключевые слова: горно-пустынная местность, тактика армейской авиации, боевые потери, поисково-спасательные операции, воинская дисциплина, авианаводчик.

Для цитирования: Гагин В.В. 2020. «Полеты, не обеспеченные в поисково-спасательном отношении, запрещаются...»: к вопросу о боевом применении авиации 40-й армии в Афганистане в 1979-1989 гг. Via in tempore. История. Политология, 47 (3): 607-617. DOI 10.18413/2687-0967-2020-47-3-607-617.

\section{«Flights that are not secured in the search and rescue are prohibited...» on the issue of combat use of 40th army aviation in Afghanistan in 1979-1989}

\author{
Vladimir V. Gagin \\ Air force Academy named after Professor N.E. Zhukovsky and Y.A. Gagarin (Voronezh), \\ 54a Staryh Bol'shevikov st., Voronezh, 394064, Russia \\ E-mail: generals78@mail.ru
}

\begin{abstract}
The article is devoted to the analysis of the combat experience of the USSR Air Force during the period of Soviet troops' participation in the war in Afghanistan in 1979-1989. The specifics of the mountainous desert terrain and climatic conditions of this country are characteristic of almost all the states with which the Russian Federation borders in the south, starting from Transcaucasia and Central Asia, and to China and Mongolia in the Far East. The combat experience acquired by the Air Force then is important today not only because of the very high price paid in 1979-1989 in Afghanistan by the blood and lives of soldiers and
\end{abstract}


officers, but also by its relevance. The equipment and weapons that are currently being used by the Russian aerospace forces, in many of their components remained either the same or modernized to various degrees, therefore, the forms and methods of working with them - operation, maintenance, supply, etc. - the former. In addition to technical issues, veterans of the war in Afghanistan - military leaders and commanders of various ranks and levels - emphasize in every way that issues of interaction and control play a special role. In order to avoid negative factors in the organization and conduct of hostilities due to poorly set interaction between the ground forces and aviation, constant improvement of command is necessary. Prepared large operations, as a rule, take place without large losses, while small unprepared often lead to failure. Therefore, the experience of organizing the interaction of large operations must always be transferred to small ones.

Key words: mountain-desert terrain, tactics of army aviation, combat losses, search and rescue operations, military discipline, aircraft master.

For citation: Gagin V.V. 2020. «Flights that are not secured in the search and rescue are prohibited...» on the issue of combat use of 40th army aviation in Afghanistan in 1979-1989. Via in tempore. History and political science, 47 (3): 607-617 (in Russian). DOI 10.18413/2687-0967-2020-47-3-607-617.

30 сентября 2020 г. исполнится 5 лет со дня начала военной операции российских ВКС в Сирии. Вступление нашей страны в вооруженный конфликт позволило кардинально изменить направленность и характер боевых действий, в результате чего были достигнуты политические преимущества и установлено политическое соглашение на российских условиях. По данным Министерства обороны РФ, к августу 2018 г. в военной операции были задействованы экипажи следующих видов авиации: оперативно-тактическая (87 \%), армейская (91\%), Военно-транспортная авиация (97\%), стратегическая и Дальняя авиация $(60 \%)$. Летчики ВКС совершили 39 тысяч боевых вылетов.

Сирийский боевой опыт, часто выявляющий негативные последствия бессистемности постперестроечного военного строительства новой России просто требует от исследователей в области истории отечественной авиации как можно более разностороннего и объективного изучения процессов строительства ВВС советского периода. Несмотря на то, что российские ВКС успешно выполняют поставленные задачи, они несут потери (на 22 августа 2018 г. официально сообщалось о 14 летательных аппаратах). На наш взгляд, потерь могло стать несколько меньше, если бы полностью учитывался опыт, приобретенный советскими ВВС в период боевых действий в Афганистане в 1979-1989 гг. Афганские события дали мощнейший толчок развитию тактики применения армейской авиации, изменили не только систему взаимодействия между родами войск и видами ВС, но и значительно подняли роль и значение вертолётов в боевых действиях, особенно в горно-пустынной местности. В то же время афганский опыт обобщался и использовался лишь в частях и соединениях 40-й армии и почти не нашел отражения в боевых уставах и наставлениях в постперестроечный период.

Данная публикация посвящена анализу боевых действий армейской и фронтовой авиации советских ВВС в Афганистане в 1979-1989 гг., накопленный опыт которых является актуальным и востребованным и в наши дни. В частности, на основе опыта крупномасштабных операций с участием винтокрылых машин в ВBC 40-й армии (А) и 73-й воздушной армии (BА) в Афганистане появились разнообразные предложения по совершенствованию тактики их применения - транспортные, огневые и маневренные качества вертолетов оказались не только постоянно востребованными, но и незаменимыми.

Анализ боевой деятельности советской авиации в указанный период позволяет сделать ряд рекомендаций и предложений, которые позволят улучшить подготовку пилотов российских ВКС. Представляется небезынтересным обозначить трудности применения армейской вертолетной авиации, которые не потеряли своей актуальности в современном афганском конфликте. По словам пилота-контрактника из ЮАР Нила Эллиса (Neall Ellis), летавшего в Афганистане на вертолете российского производства Ми-8МТВ в 2000-х гг., иррегулярные войска активнее действуют в жилых зеленых зонах, нежели на высокогорных и труднодо- 
ступных участках. В этой связи он обычно выбирал полетный маршрут над сложным рельефом. По данным Эллиса, авиаторы из стран Восточного блока (русские и украинцы), напротив, к использованию тактики часто относятся с пренебрежением. Они летают на не скоростных, крейсерских режимах и по многократно исхоженным, шаблонным маршрутам, из-за чего и попадают под обстрел из засады. Что касается надежности российской техники, у южноафриканского летчика наилучшие отзывы о вертолете Ми-8 с двигателями ТВ3-117ВМ, который разработали специально для действий в условиях Афганистана. С отказом двигателя он столкнулся лишь однажды, но даже с грузом на борту смог стабилизировать машину на высоте 2440 м. Как выяснилось впоследствии, причиной стало засорение топливного фильтра металлическими опилками от регулятора подачи топлива [Alleace, 2012, p. 18].

Афганский опыт, забытый в 1990-х гг., когда подготовка летчиков из-за нехватки керосина была просто ничтожной, вновь актуализируется. В настоящее время российское командование старается обеспечить максимально возможный налет. В среднем у каждого пилота выходит более 200 часов. Признается польза подготовки на тренажерах, когда летчик видит последствия принятых им в полете решений в реальном времени. Одна из проблем тренажеров заключается в отсутствии привязки некоторых старых систем к конкретным ландшафтам предполагаемых театров военных действий.

Минимум один раз в год производятся сборы по пуску управляемых ракет. Парашютная подготовка предусматривает не менее двух прыжков в год.

Анализ боевых потерь в Афганистане показал острую необходимость повышения уровня защиты экипажей. Зачастую уцелевший при обстреле экипаж спасал даже сильно поврежденную машину. Простое добавление боковых бронестекол привело к ухудшению обзора и уменьшению полезного объема кабины. Защитный комплект вертолетчика образца 1980 г. - фактически стальные латы - был слишком громоздким и тяжелым. Из-за чрезмерно тяжелого веса бронежилетов и защитных шлемов ЗШ-ЗБ экипажи пользовались ими крайне редко (позднее стали поступать более практичные титановые ЗШ-5Б). Легкие синтетические голубые комбинезоны при пожаре плавились и оставляли на коже тяжелые ожоги, поэтому были заменены костюмами из натуральных материалов. Основным противопожарным мероприятием стало заполнение топливных баков вертолетов губкой из пенополиуретана. На случай вынужденной посадки на территории, захваченной противником, экипажи всячески увеличивали свой боезапас, оставляя лишь шоколад и флягу с водой.

Летчики вертолетов Ми-24 многократно высказывали пожелание установить на свои «крокодилы» пулеметы для стрельбы назад во время выхода из атаки, т. к. 46-48 \% всех попаданий эти боевые вертолеты получали именно тогда. У транспортно-боевых Ми-8 такой кормовой пулемет был, и это уменьшало печальную статистику до $26-27$ \%. Все попытки доработок в этом направлении оказались малоэффективными и не прижились. Нет возможности стрелять в заднюю полусферу у российских боевых вертолетов и сегодня.

Экипажи «крокодилов» обходились прикрытием стрелка-борттехника, который вел стрельбу назад, для чего он дополнительно брал с собой один, а то и два пулемета ПКТ. Во многих случаях это спасало вертолет, поэтому предложение командования ВВС 40-й армии оставлять борттехника на земле для сокращения возможных потерь личного состава вызвало протест со стороны самих экипажей.

Значительные превышения аэродромов и посадочных посадок (до 2500 м) в Афганистане приводили к вынужденному уменьшению запаса топлива и боевой загрузки (высокая температура и разряженность воздуха естественно сокращают тактический радиус летательных аппаратов и время нахождения их над полем боя, а следовательно, и время огневого воздействия на противника).

На соплах двигателей для защиты от тепловых головок ракет ПЗРК ${ }^{174}$ устанавливались эжекторы (ЭВУ) ${ }^{175}$. Они прижились не сразу по причине большого сопротивления и не-

174 Переносной зенитный ракетный комплекс. 
удобства в эксплуатации, став обязательными лишь с 1983 г., когда увеличилась угроза поражения ракетным комплексом. Комплекс мероприятий радиоэлектронной борьбы включал с 1987 г. кассеты ИК-ловушек ${ }^{176}$ АСО-2В ${ }^{177}$. Станция активных помех СОЭП-В1А «Липа» в применении также показала свою высокую эффективность и незаменимость: в случае ее отказа экипаж пристраивался над другим вертолетом, на котором станция была исправна ${ }^{178}$.

Инфракрасные ловушки с 1985 г. стали основным техническим средством защиты самолетов и вертолетов. В частности, на Су-17 устанавливалось от 4 до 12 балок АСО-2В (позднее АСО-28И). В каждой балке находилось по 32 пиропатрона, начиненных термитной смесью. Серьезной защитой являлись также 12 более мощных патронов ЛО-43 ${ }^{179}$. При взлете и посадке, а главное - в зоне действия вражеской ПВО пилот включал автомат отстрела ловушек, отвлекавших на себя самонаводящиеся «Стрелы» и другие типы ракет ПЗРК. Боевые вылеты самолетов и вертолетов, не снаряженных пиропатронами, не допускались.

Нельзя обойти вниманием проблемы, связанные с материальной частью вертолетов, которые удалось устранить далеко не все. Например, многие улучшения по «афганским» предложениям, касавшиеся модернизации системы управления, - установки демпферов и более мощных гидроусилителей - не были внедрены. Оборудование вертолетов впрыском воды на вход двигателей привело к появлению новых проблем в области управления и эксплуатации [Марковский, 2000, с. 99]. Чрезмерно избыточный вес вертолетов Ми-24 преодолели установкой на модернизированные машины Ми-35 неубирающегося шасси.

Говоря об опыте устранения технических проблем самолетов и вертолетов в ДРА нельзя не упомянуть беспрецедентный пример совершенствования матчасти армейской авиации в боевых условиях. Речь идет об истории принятия на вооружение и доработки по результатам войсковых испытаний самолета-штурмовика конструкции ОКБ им. П.О. Сухого Су-25 «Грач». Созданный в конце 1970-х гг. как самолет непосредственной огневой поддержки сухопутных войск, Су-25 был сконструирован с учетом новейших достижений отечественного самолетостроения и металловедения по самым высоким требованиям к живучести боевых летательных аппаратов, с многократным дублированием основных систем [Бедретдинов, 1994, с. 78-85]. Благодаря Главнокомандующему ВВС СССР Главному маршалу авиации П.С. Кутахову, сумевшему увидеть в новом самолете будущее надежное и эффективное оружие, подобное прославленному штурмовику Ил-2, буквально первые предсерийные образцы были направлены в высокогорный Шинданд. Было налажено теснейшее взаимодействие, и малейшие замечания или пожелания инженерно-авиационной службы BBC 40-й А по опыту эксплуатации Су-25 без промедления отправлялись в Москву. Инженеры и конструкторы ОКБ им. П.О. Сухого так же быстро реагировали на заявки военных срочными доработками. Совместные усилия специалистов ОКБ, летно-технического состава сначала опытной авиаэскадрильи, а затем и полка штурмовиков дали выдающийся результат, оправдавший самые смелые ожидания: штурмовик Су- 25 стал поистине самолетомсолдатом, незаменимым для поддержки пехоты и грозным для врагов [Самойлович, 1999, c. 69]. Этот самолет и сегодня, спустя сорок лет, состоит на вооружении ВКС РФ.

За период пребывания советских войск в Афганистане ВВС потеряли 333 вертолета [Отечественная военная история, Т. 2-3, 2003, с. 535] (28 Ми-6, 174 Ми-8 и 127 Ми-24,

175 ЭВУ - эжектор с удлиненной цилиндрической камерой смешения, имеющий в 1,5-2 раза большие значения КПД.

176 Пиротехнические устройства, выделяющие большое количество тепла при сгорании горючего состава.

177 Авиационное устройство автоматической постановки радиолокационных и инфракрасных помех.

178 Шканакин В.Г. Доклад командующего ВВС 73 ВА. Основные способы ведения боевых действий и тактические приемы армейской авиации в условиях горно-пустынной местности. Особенности организации подготовки экипажей вертолетов // Архив библиотеки ВУНЦ ВВС «ВВА». Сборник материалов по боевому применению ВВС 40-й армии в 1979-1989 гг. Т. 9. Л. 383.

179 Инфракрасная ловушка, представляющая собой мощный пиропатрон - ложную тепловую цель для ракет ПЗРК противника. 
4 Ми-9 и Ми-10). Что касается потерь афганской армии, то они составили 338 Ми-8/17 и Ми-25/35. Анализируя боевые потери по типам вертолетов, можно прийти к выводу, что больше всего потеряно вертолетов Ми-8, в среднем 49 \% от общего количества потерь. Этих вертолетов в процентном отношении в ВВС 40-й армии было больше по сравнению с другими типами летательных аппаратов (ЛА), на них возлагалось много задач, значительно больше у них был и налет. Средний налет за год на вертолетах Ми- 8 составлял 430 часов, что на 100-150 часов больше по сравнению с другими типами вертолетов и на 200250 часов больше по сравнению с боевыми самолетами. Следует подчеркнуть, что вертолеты, выполняя полеты на больших высотах, вблизи перевалов и особенно с грузом, обладали малым диапазоном маневренных характеристик. В этих условиях винтокрылая машина была легкой мишенью для противника.

В ходе выполнения боевых задач в Афганистане советские летчики накапливали опыт предотвращения потерь. Был выработан широкий комплекс рекомендаций, необходимость следования которым остается очевидной и сегодня, спустя более 30 лет после вывода советских войск из южно-азиатской страны. Этот комплекс включает выбор (на стадии разработки плана) наименее опасных маршрутов, выход на цель с применением целого набора тактических приемов, использование рельефа местности для скрытности и т. п. Пилотам необходимо постоянно следить за возможными пусками ПЗРК. В случае пуска ракеты энергичным маневром избегать попаданий, для чего уходить в сторону солнца, ярко освещенных и нагретых им горных склонов или плотной облачности. При взлете и посадке самолетов значительную роль играют патрулирующие зону вокруг аэродрома вертолеты, поскольку первые в эти моменты летят на небольшой скорости и недостаточно маневренны. Все удары наносятся с первого захода, не допуская повторных атак. Кроме того, поскольку при вводе ОКСВ в Афганистан ожидалось вмешательство авиации западных держав и соседних Китая, Ирана и Пакистана, туда были направлены самолетыистребители. Они привлекались для уничтожения иностранных летательных аппаратов, нарушающих государственную границу Афганистана, и осуществляли прикрытие бортов штурмовой и бомбардировочной авиации 40-й армии и ВВС ДРА [Ильин, 2000, с. 15].

Необходимо также отметить, что в частях ВВС 40-й армии мало внимания, к сожалению, уделялось морально-психологической подготовке летного состава и грамотным действиям при боевом повреждении авиационной техники и ее отказах. Уровень подготовки летного состава к боевому вылету, качество проведения тренажей по действиям в особых случаях в полете часто не соответствовали реалиям боевой обстановки. Имели место случаи, когда при обстрелах и боевых повреждениях пилоты «сами себе усложняли обстановку». Так, в 262-й ОВЭ летчик 2-го класса капитан Кухтин при боевом повреждении путевого управления создал такое положение вертолету Ми-8, в результате которого была полностью потеряна управляемость машиной, что привело к гибели двух членов экипажа.

К сожалению, и в наши дни нередки случаи поверхностного подхода к боевой подготовке и упрощенчества во время боевой учебы. Представляется, что отклонение от указанных правил, написанных в буквальном смысле кровью и имевших в Афганистане силу закона, должно влечь за собой дисциплинарную, а в случае потери летательного аппарата и более серьезную ответственность провинившихся командиров. Между тем, судя по данным открытых источников, эти правила не раз нарушались. Например, 18 февраля 2000 г. при выполнении боевого задания в Чечне был сбит вертолет Ми-8 тульского вертолетного полка. Поскольку ответных мер со стороны боевиков не ожидалось, то вертолеты Ми-8 не были прикрыты боевыми Ми-24. В итоге винтокрылые машины в районе десантирования в Аргунском ущелье столкнулись с плотным огнем противника с земли. Ведущему Ми-8 были нанесены серьезные повреждения, а ведомый вертолет был сбит. Все 15 человек, находившиеся на борту вертолета, погибли.

Еще одной мерой, выработанной в Афганистане в целях недопущения потерь от вражеских ПЗРК, стало строгое соблюдение правил взлета и посадки по «укороченной 
схеме». Самолет при взлете увеличивал высоту на форсаже по спирали, при этом постоянно находясь в пределах патрулируемой зоны вокруг аэродрома до выхода на безопасный эшелон. Во время посадки применялось снижение «с большим градиентом потери высоты» с обязательным (как и на взлете) отстрелом тепловых ловушек. Однако эта «посадка по градиенту», получившая также название «афганский заход», была довольно сложной и требовала высокой техники пилотирования. Тем не менее этот маневр практиковался и в других родах авиации, в том числе и военно-транспортной.

Важнейшую роль играет взаимодействие ВВС с сухопутными войсками. Опыт использования вертолетных частей в дивизиях сухопутных войск показал, что армейской авиации необходим единый орган управления, который занимался бы планированием, боевой подготовкой, решал методические и кадровые задачи, организовывал бы взаимодействие с армейскими частями и соединениями. Во многом именно этот опыт послужил основанием для передачи армейской авиации из ВВС в сухопутные соединения и объединения. Сегодня общевойсковая армия, как в конце 1970-х гг., практически вновь не имеет своей авиации и группы наведения.

Причем, как это часто бывает, некоторые специалисты видят выход из положения совершенно в иной плоскости, нежели подготовка высококлассных авианаводчиков в специальных школах, а планы реализации таких программ не подразумевают решения проблем сегодня или завтра, скорее выдавая желаемое за действительное: «Робот, оснащенный искусственным интеллектом, должен с высокой точностью наводить авиацию даже на точечные цели на поле боя. Эксперты считают, что это повысит эффективность авиаударов и поможет лишний раз не подвергать жизни военнослужащих опасности. Во время боя роботынаводчики будут работать самостоятельно, точнее, при минимальном вмешательстве операторов». Далее читателям сообщается, что «робот определит, какая цель находится перед ним. Искусственный интеллект выберет вид оружия, которым лучше всего уничтожить технику и живую силу противника, а также отличит своих от чужих».

Как видим, для безответственных писателей проблема создания искусственного интеллекта уже решена... Между тем, военная специальность передового авианаводчика (ПАН) была в Афганистане и сейчас считается одной из самых опасных. В армиях наших потенциальных противников эту работу выполняют высокопрофессиональные бойцы спецназа, ибо ПАНы всегда идут в первом эшелоне войск, а зачастую они осуществляют целеуказание и корректируют огонь, находясь в тылу врага. Именно поэтому в Афганистане мятежники специально вели охоту за ПАНами, понимая, что во многом от эффективности взаимодействия мотострелков, десантников или танкистов с армейской авиацией зависит исход боя или даже всей операции. Недаром за каждого убитого или взятого в плен авианаводчика душманам обещали щедрое вознаграждение ${ }^{180}$.

Профессиональный подход к выбору эффективных направлений решения той или иной давно назревшей проблемы подразумевает слаженную и планомерную работу на всех уровнях на базе всестороннего анализа бесценного боевого опыта Афганистана, Чечни и Сирии.

Во время войны в Афганистане военные авиаторы хорошо понимали важность накапливания, осмысления и передачи боевого опыта. Эта тема красной нитью проходит через многие боевые и отчетные документы. Например, в справке «Итоги боевой деятельности ВВС 40 А в 1987 году» начальник штаба ВВС 40-й армии полковник А. Божко, подчеркивая, что авиация ведет «активные боевые действия в условиях сложной военнополитической обстановки и значительно возросшей активности средств ПВО мятежников, сосредотачивая главные усилия на совместных боевых действиях с сухопутными войсками по разгрому бандформирований в базовых районах и в опорных пунктах, караванов,

180 Лекция командующего ВВС ТуркВО на тему: «Силы и средства фронта, армейской авиации, способы их применения в операциях начального периода»// Архив библиотеки ВУНЦ ВВС «ВВА». Сборник материалов по боевому применению ВВС 40-й армии в 1979-1989 гг. Т. 9. Л. 353. 
складов, а также на ведении самостоятельных боевых действий», сначала приводил общие статистические данные, а затем вместе с кратким анализом делал большой акцент на необходимости систематического сбора и постоянного использования боевого опыта.

Следует подчеркнуть, что 1987 год по интенсивности боевой деятельности ВВС 40-й армии относится к одному из самых напряженных за весь период военных действий в Афганистане. Так, за январь-февраль по состоянию на 26 февраля выполнено 17380 боевых вылетов с налетом 19445 часов, в том числе:

- на выполнение БШУ ${ }^{181}$ - 3066 часов, 2371 вылет;

- на авиационную поддержку - 112 часов, 129 вылетов;

- на воздушную разведку - 4126 часов, 4286 вылетов.

При этом по сравнению с аналогичным периодом прошлого года, количество БШУ уменьшилось на $10 \%$, количество полетов на авиационную поддержку - на 48 \%, на воздушную разведку - на $10 \%$.

Детальное сравнение приведено в таблице:

Таблица

Table

Виды и интенсивность боевых действий ВВС 40-й армии в январе-феврале 1986-1987 гг.

\begin{tabular}{|l|c|c|c|c|c|}
\hline \multirow{2}{*}{\multicolumn{1}{|c|}{ Виды боевых действий }} & \multicolumn{3}{|c|}{ Выполнено с 1.01. по 26.02. } & \multirow{2}{*}{$\%$} \\
\cline { 2 - 5 } & \multicolumn{2}{|c|}{1986 г. } & \multicolumn{2}{c|}{1987 г. } \\
\cline { 2 - 5 } & Вылетов & Налет & Вылетов & Налет & \\
\hline Всего & 27129 & 26484 & 17380 & 19445 & 64 \\
\hline Из них: & & & & & \\
\hline БШУ & 3286 & 3380 & 3066 & 2371 & 90 \\
\hline Авиаподдержка & 2333 & 2207 & 1112 & 1126 & 62 \\
\hline Прикрытие & 526 & 480 & 316 & 404 & 48 \\
\hline Воздушная разведка & 4313 & 4302 & 4126 & 4286 & 90 \\
\hline Патрульное сопровождение & 3979 & 3789 & 4580 & 3743 & 114 \\
\hline Десантирование & 1668 & 718 & 156 & 161 & 18 \\
\hline Минирование & 282 & 271 & 109 & 103 & 38 \\
\hline ОБУ 182 & 361 & 713 & 50 & 130 & 13 \\
\hline ПСО 183 & 1375 & 2859 & 776 & 712 & 56 \\
\hline Перевозки & 8528 & 8047 & 5666 & 4880 & 65 \\
\hline
\end{tabular}

Приведенные данные показывают, что интенсивность боевых действий ВВС за указанный период, по сравнению с предыдущим 1986 г., незначительно снизилась. Причиной являлось заключение перемирия и в связи с этим запрет на ведение боевых действий.

Полковник Божко отмечал, что оснащение банд мятежников современными средствами ПЗРК «Стингер», «Блоу-Пайп», «Стрела-2», улучшение подготовки операторов привело к увеличению потерь летательных аппаратов. Всего потеряно 6, в т. ч. самолетов - 3, вертолетов - 3, из них 4 - от ПЗРК. Это потребовало изменить тактику применения авиации.

Удары стали наноситься с большими углами пикирования и заключительным выводом из атаки на высоте не менее 3000 м над целью, что обеспечивало удар без входа или с минимальным временем (3-4 секунды) пребывания в зоне поражения ПЗРК, при этом точность ударов оставалась хорошей.

Несколько перераспределилась боевая нагрузка. Более интенсивно стали использоваться скоростные самолеты МиГ-23, Су-17M3, и меньше стали привлекаться для ударов Су-25 как менее скоростные.

\footnotetext{
${ }^{181}$ Бомбоштурмовые удары.

182 Обеспечение боевого управления.

183 Поисково-спасательные операции.
} 
Авиация в операциях применялась в основном массированно, большими ударными группами с длительным огневым воздействием на противника. Такая тактика действий обеспечивала высокую плотность огня, эффективность поражения, исключала возможность мятежникам вести прицельный огонь на поражение самолетов и исключала потери.

Широко применялись массированные удары фронтовой авиации в сумерках и ночью.

Большое распространение получили разведывательно-ударные действия (РУД) по уничтожению караванов мятежников как днем, так и ночью. Всего было выполнено 496 вылетов на РУД ${ }^{184}$, вскрыто 36 караванов.

Интенсивно наносились удары по базовым районам: Хост, Шиннарай, Исламдара, Анардара, Верхний Панджшер. Всего нанесено 419 бомбоштурмовых ударов.

Выполнен большой объем перевозок материально-технических средств 3285 тонн и личного состава - 2420 человек.

С целью поддержания натренированности и ввода летного состава в строй регулярно проводились учебно-тренировочные полеты. В прошедшем периоде было проведено 2020 вылетов с налетом 939 часов, что обеспечивало поддержание боевой готовности экипажей.

По данным агентурной разведки ударами авиации было уничтожено:

- мятежников - 565;

- автомашин - 12 ;

- ДШК ${ }^{185} / 3$ ГУ $^{186}-37 / 29$;

- ПЗРК -12 ;

- РПГ ${ }^{187}-33$;

- вьючных животных - 179.

Кроме того, разгромлено:

- крепостей - 16;

- огневых позиций - 8;

- складов - 17;

- караванов - 21 .

По мнению начальника штаба ВBC 40-й А, части ВBC с поставленными боевыми задачами справились. Летный состав приобрел определенный боевой опыт в выполнении самых сложных задач в условиях горно-пустынной местности: «В лучшую сторону среди других авиационных частей выделяются 190 ИАП ${ }^{188}, 239$ ОВЭ ${ }^{189}, 254$ ОВЭ. Здесь инициативно, творчески обобщался и изучался боевой опыт и настойчиво внедрялся в боевую деятельность. В целом с хорошим качеством решали боевые задачи 166 АПИБ ${ }^{190}, 378$ ОШАП ${ }^{191}, 181$ ОВП ${ }^{192}, 262$ ОВЭ. Ниже своих возможностей работали 50 ОСАП ${ }^{193}, 335$ ОВП и 280 ОВП» ${ }^{194}$.

Подводя итог, А. Божко подчеркнул, что «в целях повышения эффективности боевых действий и снижения боевых потерь перед нами стоит главная задача: настойчиво продолжать совершенствование и изыскивать новые тактические приемы и способы бое-

184 Разведывательно-ударные действия.
185 Советский пулемет Дегтярева - Шпагина крупнокалиберный.
186 Зенитная горная установка.
187 Ручной противотанковый гранатомет.
188 Истребительный авиационный полк.
189 Отдельная вертолетная эскадрилья.
190 Авиационный полк истребителей-бомбардировщиков.
191 Отдельный штурмовой авиационный полк.
192 Отдельный вертолетный полк.
193 Отдельный смешанный авиационный полк.
${ }_{194}$ Божко А. Справка «Итоги боевой деятельности ВВС 40 А в 1987 году» // Архив библиотеки ВУНЦ ВВС «ВВА». Сборник материалов по боевому применению ВВС 40-й армии в 1979-1989 гг. Т. 4. ЛЛ. 120-123. 
вых действий, совершенствовать боевую технику и вооружение, готовить летный состав к ведению боевых действий в любых условиях боевой обстановки» ${ }^{195}$. Как показало время, эти выводы являются актуальными и в наши дни.

Следует подчеркнуть, что, благодаря дальновидности советских военачальников высшего ранга, афганский опыт по целому ряду приказов в штабах ОКСВ стали копить и систематизировать сразу же по прибытии в ДРА. Вызывает не только интерес, но и трогательное восхищение тот факт, что первый журнал боевых действий и хроники военных событий штаба авиационной группировки, начатый сразу по прибытии в Кабул, несколько недель заполнялся писарем от руки - на новом месте в суматохе обустройства элементарно не хватало пишущих машинок. В итоге были собраны тысячи бесценных документов, представляющих как огромный исторический, так и военно-прикладной интерес: приказы, распоряжения, донесения, формы отчетных рапортов, рабочие карты и схемы не только воздушных операций, но и организации и связи, снабжения, охраны аэродромов и т. п.

В настоящее время исследователи, имея возможность сравнить промежуточную статистику ОКСВ по многим параметрам с аналогичной американской и натовской, находят множество подтверждений, свидетельствующих о высокой боевой выучке советского командного состава, его оперативном военном искусстве, мастерстве в применении того или иного приема тактики. Анализируя результаты боевых действий советских солдат и офицеров различных родов войск в Афганистане, включая и ВBC, можно найти многочисленные примеры героизма личного состава, показавшего образцы храбрости и самоотверженности. Постоянное обращение к боевому опыту ОКСВ в Афганистане в полной мере актуально до сих пор. Именно этот опыт необходимо неустанно и неформально изучать как в организации боевой подготовки, так и при участии в боевых действиях, например, в Сирийской Арабской Республике. К сожалению, такое всегда плодотворное обращение происходит не часто и, как следствие, приводит к неоправданным потерям политического реноме, боевой техники, а главное - личного состава.

\section{Список литературы}

1. Аблазов В. Советские соколы в Афганистане в первый год войны. URL: http://www.airwar.ru/history/locwar/afgan/afgan1/afgan2.html (дата обращения: 28.03.2020).

2. Авиация в Афганской войне 1979-1989 гг. URL: http://www.modernarmy.ru/article/208 (дата обращения: 28.03.2020).

3. Бедретдинов И. 1994. Штурмовик ОКБ П.О. Сухого Су-25. Москва, ИЧП «Кучково поле», 248.

4. Божко А. Справка «Итоги боевой деятельности ВВС 40 А в 1987 году». Архив библиотеки ВУНЦ ВВС «ВВА». Сборник материалов по боевому применению ВВС 40-й армии в 1979-1989 гг. Т. 4.

5. Генерал Сурцуков. Армейская авиация в небе Афганистана. URL: http://zavtra.ru/blogs/general_surtcukov_-_armejskaya_aviatciya_v_nebe_afganistana (дата обращения: 28.03.2020).

6. Дандыкин В. Винтокрылое братство. URL: http://www.redstar.ru/index.php/syria/item/ 26357-vintokryloe-bratstvo (дата обращения: 26.09.2018).

7. Ильин В.Е. 2000. МиГ-23: долгий путь к совершенству. Авиация и Время. 2: 3-21.

8. Коваленко Н., Нечаев А. Три главные версии катастрофы Ан-26 в Сирии URL: http://vz.ru/society/2018/3/7/877273.html (дата обращения: 11.09.2018).

9. Лекция командующего ВВС ТуркВО на тему: «Силы и средства фронта, армейской авиации, способы их применения в операциях начального периода». Архив библиотеки ВУНЦ ВВС «ВВА». Сборник материалов по боевому применению ВВС 40-й армии в 1979-1989 гг. Т. 9.

10. Марковский В.Ю. 2000. Жаркое небо Афганистана. Москва, «Техника - молодежи», 104.

11. Марковский В.Ю. Ми-24 в Афганистане. URL: http://www.airwar.ru/history/locwar/afgan/mi24/mi24.html (дата обращения: 28.03.2020). 
12. Минобороны подвело итоги операции в Сирии. URL: https://tass.ru/armiya-iopk/5479447 (дата обращения: 28.03.2020).

13. Мокрушин Д. «Я - вертолетчик». Часть третья. URL: http://topwar.ru/87159-yavertoletchik-chast-tretya.html (дата обращения: 26.09.2018).

14. Никольский M. Прощание с экипажем сбитого Ми-8. Грозный-Северный URL: http://profilib.net/chtenie/132572/aviatsiya-i-kosmonavtika-2008-09-lib-3.php (дата обращения: 08.09.2018).

15. Отечественная военная история. В трех томах. Т. 2-3. 2003. М., Издательский дом «Звонница-МГ», 656.

16. Потери авиации Минобороны РФ в сирийской кампании. URL: https://tass.ru/info/5575669 (дата обращения: 28.03.2020).

17. Самойлович О. 1999. Рядом с Сухим. Воспоминания авиаконструктора. Москва, «От винта!», 136.

18. Степовой Б., Рамм А. Робот наведет авиацию с высокой точностью. URL: https://iz.ru/773334/bogdan-stepovoi-aleksei-ramm/robot-navedet-aviatciiu-s-vysokoi-tochnostiu (дата обращения: 23.03.2020).

19. Ходаренок M. «Афганский заход»: почему Ан-26 упал в Сирии. URL: http://www.gazeta.ru/army/ 2018/03/07/11675035.html (дата обращения: 11.09.2018).

20. Ходаренок M. Афганская кампания: невостребованный опыт. URL: https://topwar.ru/41301afganskaya-kampaniya-nevostrebovannyy-opyt.html (дата обращения: 28.03.2020).

21. Шканакин В.Г. Доклад командующего ВВС 73ВА. Основные способы ведения боевых действий и тактические приемы армейской авиации в условиях горно-пустынной местности. Особенности организации подготовки экипажей вертолетов. Архив библиотеки ВУНЦ ВВС «ВВА». Сборник материалов по боевому применению ВВС 40-й армии в 1979-1989 гг. Т. 9.

22. Alleace N. 2012. Chopper Support Missions. Combat \& Survival. November: 21-27.

\section{References}

1. Ablazov V. Sovetskie sokoly v Afganistane v pervyj god vojny [Soviet falcons in Afghanistan in the first year of the war]. URL: http://www.airwar.ru/history/locwar/afgan/afgan1/afgan2.html (date accessed: 28.03.2020) (in Russian).

2. Aviacija v Afganskoj vojne 1979-1989 gg. [Aviation in the Afghan war 1979-1989]. URL: http://www.modernarmy.ru/article/208 (date accessed: 28.03.2020) (in Russian).

3. Bedretdinov I. 1994. Shturmovik OKB P.O. Suhogo Su-25 [P.O. Sukhoi SU-25 attack aircraft design Bureau]. Moscow, IPB Kuchkovo field, 248 (in Russian).

4. Bozhko A. Spravka «Itogi boevoj dejatel'nosti VVS 40 A v 1987 godu». Arhiv biblioteki VUNC VVS «VVA». Sbornik materialov po boevomu primeneniju VVS 40-j armii v 1979-1989 gg. [Reference Results of combat activity of the 40 A air force in 1987». The archive library of MESC AF. Collection of materials on combat use of the air force of the 40th army in 1979-1989. Vol. 4].

5. General Surcukov. Armejskaja aviacija v nebe Afganistana [General Surtsukov. Army aviation in the skies of Afghanistan]. URL: http://zavtra.ru/blogs/general_surtcukov__armejskaya_aviatciya_v_nebe_afganistana (date accessed: 28.03.2020) (in Russian).

6. Dadykin V. Vintokryloe bratstvo [Rotary-wing brotherhood] URL: http://www.redstar.ru/index.php/syria/item/ 26357-vintokryloe-bratstvo (date accessed: 26.09.2018) (in Russian).

7. Ilyin V.E. 2000. MiG-23: dolgij put' k sovershenstvu [MiG-23: a long way to perfection]. Aviation and Time. 2: 3-21 (in Russian).

8. Kovalenko N., Nechaev A. Tri glavnye versii katastrofy An-26 v Sirii [Three main versions of the An-26 crash in Syria]. URL: http://vz.ru/society/2018/3/7/877273.html (date accessed: 26.09.2018) (in Russian).

9. Lekcija komandujushhego VVS TurkVO na temu: «Sily i sredstva fronta, armejskoj aviacii, sposoby ih primenenija $\mathrm{v}$ operacijah nachal'nogo perioda». Arhiv biblioteki VUNC VVS «VVA». Sbornik materialov po boevomu primeneniju VVS 40-j armii v 1979-1989 gg. [Lecture of the commander of the air force of Turkestan military district on the topic: «Forces and means of the front, army aviation, ways of their application to operations of the initial period». The archive library of MESC AF. Collection of materials on combat use of the air force of the 40th army in 1979-1989. Vol. 9]. 
10. Markovsky V.Yu. 2000. Zharkoe nebo Afganistana [Hot sky of Afghanistan]. Moscow, «Technique to the youth», 104 (in Russian).

11. Markovsky V.Yu. Mi-24 v Afganistane [Mi-24 in Afghanistan]. URL: http://www.airwar.ru/history/locwar/afgan/mi24/mi24.html (date accessed: 28.03.2020) (in Russian).

12. Minoborony podvelo itogi operacii v Sirii [The defense Ministry has summed up the results of operation in Syria]. URL: https://tass.ru/armiya-i-opk/5479447 (date accessed: 28.03.2020) (in Russian).

13. Mokrushin D. «Ja - vertoletchik». Chast' tret'ja [«I am a helicopter pilot». Part three]. URL: http://topwar.ru/87159-ya-vertoletchik-chast-tretya.html (date accessed: 26.09.2018) (in Russian).

14. Nikolsky M. Proshhanie s jekipazhem sbitogo Mi-8. Groznyj-Severnyj [Farewell to the crew of the downed Mi-8. Grozny-Severny]. URL: http://profilib.net/chtenie/132572/aviatsiya-i-kosmonavtika2008-09-lib-3.php (date accessed: 26.09.2018) (in Russian).

15. Otechestvennaja voennaja istorija. V treh tomah. T. 2-3. 2003 [Russian military history. In three volumes. Vol. 2-3] M., Publishing house «Belfry-MG», 656 (in Russian).

16. Poteri aviacii Minoborony RF v sirijskoj kampanii [Russian defense Ministry aviation losses in the Syrian campaign]. URL: https://tass.ru/info/5575669 (date accessed: 28.03.2020) (in Russian).

17. Samoilovich O. 1999. Ryadom s Suhim. Vospominaniya aviakonstruktora [Next to Sukhoi. Memories of an aircraft designer]. Moscow, «Ot vinta!», 136 (in Russian).

18. Stepovoy B., Ramm A. Robot navedet aviaciju s vysokoj tochnost'ju [Robot will direct aviation with high accuracy]. URL: https://iz.ru/773334/bogdan-stepovoi-aleksei-ramm/robot-navedetaviatciiu-s-vysokoi-tochnostiu (date accessed: 28.03.2020) (in Russian).

19. Shkanakin V.G. Doklad komandujushhego VVS 73VA. Osnovnye sposoby vedenija boevyh dejstvij i takticheskie priemy armejskoj aviacii v uslovijah gorno-pustynnoj mestnosti. Osobennosti organizacii podgotovki jekipazhej vertoletov Arhiv biblioteki VUNC VVS «VVA». Sbornik materialov po boevomu primeneniju VVS 40-j armii v 1979-1989 gg. [Report of the commander of the air force of 73AA. The main methods of conducting of military operations and tactical techniques of army aviation in mountainous and desert terrain. Features of helicopter crew training organization. The archive library of MESC AF. Collection of materials on combat use of the air force of the 40th army in 1979-1989. Vol. 9].

20. Khodarenok M. «Afganskij zahod»: pochemu An-26 upal v Sirii [«Afghan interference»: why An-26 fell in Syria]. URL: http://www.gazeta.ru/army/ 2018/03/07/11675035.html (date accessed: 26.09.2018) (in Russian).

21. Khodarenok M. Afganskaja kampanija: nevostrebovannyj opyt [Afghan campaign: unclaimed experience]. URL: https://topwar.ru/41301-afganskaya-kampaniya-nevostrebovannyy-opyt.html (date accessed: 28.03.2020) (in Russian).

22. Alleace N. 2012. Chopper Support Missions. Combat \& Survival. November: 21-27.

\section{ИНФОРМАЦИЯ ОБ АВТОРЕ}

Гагин Владимир Владимирович, старший научный сотрудник научно-исследовательского управления научно-исследовательского центра (проблем применения, обеспечения и управления авиацией ВВС) ВУНЦ ВВС «ВВА имени профессора Н.Е. Жуковского и Ю.А. Гагарина» (г. Воронеж), г. Воронеж, Россия

\section{INFORMATION ABOUT THE AUTHOR}

Vladimir V. Gagin, Senior researcher of the research Department of the research center (problems of application, provision and management of air force aviation), MESC AF «Professor N.E. Zhukovsky and Y.A. Gagarin Air Force Academy» (Voronezh), Voronezh, Russia 